\title{
Teaching English as a Foreign Language in Saudi Arabia: Struggles and Strategies
}

\author{
Tanzin Ara Ashraf \\ Department of English, King Khalid University \\ PO Box 960, Abha, Saudi Arabia \\ Tel: 2264908 E-mail: tanzen@kku.edu.sa
}

Received: March 12, 2018 Accepted: May 11, 2018 Published: May 16, 2018

doi:10.5296/ijele.v6i1.13148 URL: https://doi.org/10.5296/ijele.v6i1.13148

\begin{abstract}
This paper is based on action research carried out in King Khalid University, Saudi Arabia. The purpose of this study is to investigate the vital issues related to the teaching of English in Saudi Arabia. Some major problems include: influence of mother tongue, less exposure to English in day to day life, attitude towards teaching and learning English, lack of recent trends of EFL teaching, enrolling larger number of students in EFL classes and failure of creating effective teaching environment. The research is conducted among the first year students of Chemistry and Mathematics of King Khalid University, studying Intensive English (Blended Course) as university requirement for 12 hours a week for 15 weeks. The study proposes some remedial measures which recommend introducing English from the beginning of primary level, modern and effective teaching strategies, selecting appropriate textbooks, building sound teacher-student relationships and implementing diverse assessment methods.
\end{abstract}

Keywords: challenges, exposure to English, Saudi EFL learners, teaching strategies 


\section{Introduction}

Teaching English in Saudi Arabia is indeed challenging. Despite various measures taken by the Ministry of Education to develop the process of teaching and learning English, there is still plenty of room for improvement. Al- Nasser (2015) has stated that the influence of mother tongue works as a major obstacle to learn English. Insufficient exposure to English in day to day life, absence of English from the beginning of primary education, prevents the learners from making effective communication both in oral and written form. Students are not exposed to sufficient English as they start learning English in the last year of the primary level (Al-Nofaie, 2010). In fact, the students are well aware of the fact, that if English were introduced from the very beginning, learning English would have been easier for them. Many researchers have agreed on similar problems such as Jdetawy, 2011; Nation, 2003; Al-Abdan, 1993.

The government has made English as a compulsory subject. But, the attitude towards teaching and learning English needs to be moderated from the grass root level. Fareh (2010) has pointed out that, the inadequate teaching methodologies hinders the teaching/learning process and therefore suggests on proper training of the teachers to draw effective result. "A considerable percentage of class time is run in Arabic. Such a practice minimizes the time of exposure to English and thus the learning outcomes will not be adequately accomplished" (Fareh, 2010, p.3602). Failure of selecting appropriate textbooks is another reason for the poor achievement in EFL teaching. Rahman (2013) has identified that, the prescribed textbooks with minimal level of linguistics features fail to meet the requirements of the learners. In the school the students take English as a subject which is required to pass only. When these students finish school and come to the college with little understanding of English, it becomes difficult for them to follow even basic instructions. Limited vocabulary, grammar, organization of ideas, spelling and referencing affect their ability to communicate in writing and speaking (Al-Khasawneh, 2010). Their continual errors in syntax, morphology and pronunciation unable them to express themselves "comfortably and efficiently either when dealing with 'academic topics' or common everyday topics," (Mukattash, 1983, P.169). The learners have very little exposure to English in everyday life. "Saudi learners are left with very little opportunity to practice English apart from classroom." (Ashraf, 2015, P. 440). The books, media, entertainment sources, electronic devices in fact in every steps of life Arabic plays a dominant role. Therefore, the chances of learning and understanding English from real life situation are limited. To teach L2 language teachers cannot avoid using L1 language in order to communicate. On the contrary, the school going learners of other developing countries have a wide variety of exposure to English in their daily life. They can learn English by communicating with teachers, friends, from media, using electronic devices etc.

The EFL teachers of school, college and university need to make sure that the teaching atmosphere is enjoyable and interesting. Teachers need to set goals according to the needs of the learners before designing any course. They need to recognize and utilize effective teaching strategies to draw intended outcome. Learning is a continual process and it needs to be molded according to the expectations, needs and interests of the learners. The materials 
and facilities required for the EFL learners are not sufficient enough to meet the needs of both teachers and learners. Enthusiastic and innovative teachers even though having the urge to bring out the best in their students, often fail to do so because of dealing with a large number of students with insufficient facilities. Students, who from the beginning of their student life have become habituated of learning English from bilingual teachers, tend to reject the EFL teachers using only L2 language in the classrooms.

\section{The Statement of the Problem}

The students of Saudi Arabia start learning English from the middle school with an attitude to pass in the examination only. Moreover, the progress of study during this period does not seem to be systematic. After studying English for almost nine years the learners encounter various problems during the course of communication. In the classroom the learners lack the necessary vocabulary in order to get their meaning across and to keep the interaction going for a longer period of time (Rabab'ah, 2003). They lack the necessary skill to understand basic instructions. Most of them remain unable to write even a single error-free sentence. While reading, the learners fail to extract the meaning of specific words and texts. "Despite good planning, curriculum, textbooks, qualified teachers and effective administration, the teaching-learning process sometimes seems to be futile when the actual skill development is not up to the mark." (Khan,2011, P.69). Therefore, it is high time to introduce successful language program from the beginning of primary level, in Saudi Education Policy and making sure that plans are implemented effectively. The teachers, syllabus designers, moderators and policy makers altogether need to identify clear aims and objectives of the curriculum and thereby design learner centered syllabus to meet the challenges of teaching English. In order to overcome EFL learners' low proficiency level, Al-Shammakhi \& Al-Humaidi (2015), in their study has suggested the EFL teachers to-

-Be aware of students' different abilities in acquiring the foreign language and the pace they need for comprehension.

-Have knowledge about their students' needs and interests.

-Establish a good relationship with students to reduce their fear and anxiety of learning a foreign language.

-Encourage students to participate and express their needs through discussion, questionnaires, journals, etc.

-Train students to be self-reflective and teach them techniques for self and peer-assessment.

-Teach learners effective techniques in order to improve their levels and be active learners.

- Be supportive and enthusiastic so students can feel confident during English classes. 
- Update their knowledge and information about the use of different strategies.

- Discuss their experiences together in order to support their learners.

- Have effective techniques in selecting tasks that can fit different levels.

Unfortunately, the Saudi learners are left with very little opportunity to practice English apart from classroom. To master any language Halliday et al. (1984) suggests that: "Oral mastery depends on practicing and repeating the patterns produced by a native speaker of the foreign language". (P.16) In the institutions, in order to satisfy the query of the students teachers adapt a bilingual method. So the question of how the students are going to use English practically remains somewhat unanswered. Al-Nofaie (2010) states that "the use of Arabic was an unavoidable phenomenon"(P.77) in the classroom. Neither from home nor from school, have students got the motivation of practicing English.

The language teachers need to keep re-thinking, moderating and altering the teaching strategies in order to ensure effective teaching. Al shlowiy (2014), has suggested that according to place and generation the method of teaching varies. Teaching in Saudi Arabia is not the same as teaching in UK or in China. The Saudi learners belong to such a generation where there are plenty of attractive sources to distract their attention from studies. The social media plays a dominant role in this context. Therefore, it is the prime responsibility of the teachers to ensure an up-to-date teaching atmosphere which succeeds to grab the attention of the target learners. In order to motivate the students, Harmer (2007) suggests that, students' motivation is "far more likely to remain healthy if they are doing things they enjoy doing" ( $\mathrm{p}$. 102). Brown (2007) emphasizes on providing compatible classroom atmosphere where the learners embrace learning rather than rejecting. Recent studies on language teaching methodologies supports on providing opportunities to learners to communicate (Ellis,2008). Therefore, it is high time for the teachers to introduce new methodologies for successful classroom interactions.

Concerned authorities of the Saudi institutions need to select convenient ELT textbooks and study materials. Appropriate textbooks need to be selected which can help to develop the required basic skills of English language. Fareh (2010) argues:

Teaching materials are, in general, culturally inappropriate and this may alienate learners and instigate them to develop negative attitudes towards learning this foreign language. Many textbooks are culturally biased although their authors claim that they are designed to meet the needs of the learners of EFL.

Textbooks and materials with minimal level of linguistics features fail to meet the need of the learners and teachers. (Rahman, 2011) 


\section{1l Macrothink

\section{The Purpose of the Study}

\subsection{To diagnose the EFL teaching /earning problems in Saudi Arabia}

\subsection{To identify the causes of these problems.}

3.3 To suggest possible solutions of the existing problems.

\section{Methodology}

\subsection{Participants}

A total of 133 students of King Khalid University of the departments of Chemistry and Mathematics of Sciences and Arts College of Sarat Abidah, around 18 EFL teachers teaching in different colleges of King Khalid University, fiveEFL teachers teaching in the schools of Sarat Abidah, Khamis and Abha participated in this study. The students were studying Intensive English (Blended Learning Course) as university requirement for 12 hours a week for 15 weeks. The students were 18 to 20 years old and they have willingly participated and discussed their problems regarding teaching/learning English. Even they had tried to share possible solutions. Questionnaires, semi-structured interviews, discussions, classroom observations as well as observation on the learners participation in Blackboard, Facebook, Whatsapp and the researchers own experience were the main research tools for collecting data. EFL teachers took part in questionnaires' answering both open and close ended questions. They were interviewed by the researcher also. The English language exposure survey questionnaire was adopted from (Mango et al, 2009) in order to find out how much each individual has contacted with English.

\subsection{Data Collection System}

The tools for collecting data of this study include two different written questionnaires for students and teachers. (See Appendix A, B) The questionnaires contain both open and close-ended questions including suggestions from the participants. The researcher contacted the students and some teachers directly and distributed the printed copy of the questionnaires to some teachers through e-mails. The objectives of the survey required for the action research were explained in the appendices. The questionnaires were thoughtfully designed for identifying the attitudes, concerns, challenges and suggestions of the participants in order to find out the required steps to further improve the current state of EFL in Saudi Arabia.

The students were divided into two sections. With one section the way of teaching and interaction were very formal while with the other section teaching was informal. The progress of both sections was evaluated through individual and group activities, oral presentations, face-to face and online interactions and surprise tests.

\subsection{Data Analysis}

Several steps were taken to analyze the data collected. Collected data of the questionnaires were sorted out; percentages of the answers of each questionnaire were tabulated and studied 
thoroughly. The questionnaires contained both close and open ended questions. Online participation and interaction of the learners with the teacher also worked as tools for the research.

\section{Results and Findings}

\subsection{Questionnaire for the EFL Students}

Questionnaires were designed for learners in order to get a clearer view of the remaining problems from different perspectives. It contained seven questions along with a suggestion box. It was designed to find out the beliefs and expectations of Saudi EFL learners. Among the seven questions, the last question asked for the average score of the learners during their school years. The last question was kept with an aim to get an idea of the learners' performance in the school level. The questionnaires were distributed among 133 students. All the questionnaires were returned. It was in fact, surprising for the researcher to see the enthusiasm of the learners while answering the questions. However, the learners failed to write down suggestions correctly because of lacking in vocabulary and sense of sentence constructions. The researcher had to explain each question in detail for the better understanding of the participants. Many of the participants shared their views verbally.

Question1: Do you agree that English is important for you?

Table 1 shows that, $94.73 \%$ of the participants responded "Strongly Agree", 3.75\% responded "Agree", while $1.5 \%$ disagreed.

Table 1. Do you agree that English is important for you?

\begin{tabular}{|c|c|c|}
\hline Choices & Answer & Percentage \\
\hline Strongly Agree & 126 & $94.73 \%$ \\
\hline Agree & 5 & $3.75 \%$ \\
\hline Disagree & 2 & $1.5 \%$ \\
\hline
\end{tabular}

The percentages clearly show that, the learners do understand the importance of learning English very well. The enthusiasm already exists. If proper teaching and learning can be ensured, the learners might start showing noticeable improvement.

Question 2: Do you agree that English should be introduced from the beginning of primary level?

Table 2 shows that, $75.93 \%$ responded for "Strongly Agree", 21.05\% agreed, while 3\% disagreed. 
Table 2. Do you agree that English should be introduced from the beginning of primary level?

\begin{tabular}{|c|c|c|}
\hline Choices & Answer & Percentage \\
\hline Strongly Agree & 101 & $75.93 \%$ \\
\hline Agree & 28 & $21.05 \%$ \\
\hline Disagree & 4 & $3 \%$ \\
\hline
\end{tabular}

A larger number of the participants strongly agreed that English should be introduced from the beginning of primary level. In fact, majority of the participants opined that if they had learnt English form the early school days, they would have spoke better at least. Around, 3\% of the participants disagreed. Their main excuse was that, nobody would be there to help them at home with the study of English. But the question is, "Should the school going (Primary Level) students study at home?"

Question 3: Do you enjoy learning English?

Table 3 shows that, $18.79 \%$ of the students responded "Yes, I enjoy a lot", 45.11\% answered "Yes" and 36.09\% replied "No". The responses of the participants showed that, less number of students enjoyed learning English. Majority of the learners who had answered "Yes" belonged to the section where the student-teacher interaction was friendlier and way of teaching was informal. Even though $18.79 \%$ responded "Yes, I enjoy a lot", but school was not the source of enjoyment of learning English for many of them. Majority of these students enjoyed learning because of having siblings or parents who knew English, some love social media, some liked to watch English movies etc. In order to bring out the best in the students we need to ensure enjoyable classroom environment for the learners. We need to facilitate the learners with effective and enjoyable study materials which can fulfill the needs of the $21^{\text {st }}$ century learners.

Table 3. Do you enjoy learning English?

\begin{tabular}{|c|c|c|}
\hline Choices & Answer & Percentage \\
\hline Yes, I enjoy a lot & 25 & $18.79 \%$ \\
\hline Yes & 60 & $45.11 \%$ \\
\hline No & 48 & $36.09 \%$ \\
\hline
\end{tabular}

Question 4: Do you agree that teaching/learning process in Saudi Arabia needs improvement?

In table 4, 74.43\% answered "Strongly Agree", 22.55\% answered "Agree", 3\% answered "disagree". The learners of $21^{\text {st }}$ century do realize that the teaching/learning process needs improvement. The teachers need to remain up-to-date with the global methods of EFL teaching. 
Table 4. Do you agree that teaching/learning process in Saudi Arabia needs improvement?

\begin{tabular}{|c|c|c|}
\hline Choices & Answer & Percentage \\
\hline Strongly Agree & 99 & $74.43 \%$ \\
\hline Agree & 30 & $22.55 \%$ \\
\hline Disagree & 4 & $3 \%$ \\
\hline
\end{tabular}

Question 5: Do you think that the student-teacher relationship should be more informal?

In table $5,82.70 \%$ of the participants responded "Yes, I think so", $17.29 \%$ responded "I think so with reservation", while $0 \%$ responded "No". The percentages show that, all the learners look forward to more informal student-teacher relationship.

Table 5. Do you think that student-teacher relationship should be more informal?

\begin{tabular}{|c|c|c|}
\hline Choices & Answer & Percentage \\
\hline Yes, I think so & 110 & $82.70 \%$ \\
\hline I think so with reservation & 23 & $17.29 \%$ \\
\hline No & 0 & $0 \%$ \\
\hline
\end{tabular}

Question 6: Do you think that teacher should use Arabic in classroom?

Table 6 shows that, $6.7 \%$ of the participants answered for "Yes, I think so", 36.09\% answered "I think so with reservation", 57.14\% answered "No". It was indeed very surprising for the researcher. When the participants were asked for their responses they argued that if they were habituated in using English from their school life they would face less difficulties in learning English. In Saudi Arabia, the exposure to English in the learners' day to day life is extremely minimal. The only scope of practicing English is classroom. But, even from classrooms, the learners are being deprived from using English.

Table 6. Do you think that teacher should speak Arabic in classroom?

\begin{tabular}{|c|c|c|}
\hline Choices & Answer & Percentage \\
\hline Yes, I think so & 9 & $6.7 \%$ \\
\hline I think so with reservation & 48 & $36.09 \%$ \\
\hline No & 76 & $57.14 \%$ \\
\hline
\end{tabular}

Question 7: What were your average grade /score in English in school level? 
Surprisingly enough, $76.69 \%$ of the participants got $\mathbf{A}$ grade (95-100 marks), $10.54 \%$ got $\mathbf{B}$ grade (90-94 marks), 9.77\% got $\mathbf{C}$ grade (85-89 marks) and 3.75\% got $\mathbf{D}$ grade (80-84 marks). $76.69 \%$ of the total students obtained $\mathbf{A}$ grade in school but unfortunately they faced difficulties in all language skills: reading, writing, listening, speaking. (See Students' Table 7)

Table 7. What were your average grade /score in English in school level?

\begin{tabular}{|c|c|c|}
\hline Grades & Answer & Percentage \\
\hline A & 102 & $76.69 \%$ \\
\hline B & 14 & $10.54 \%$ \\
\hline C & 13 & $9.77 \%$ \\
\hline D & 5 & $3.75 \%$ \\
\hline
\end{tabular}

\subsection{Questionnaire for the EFL Teachers}

Questionnaire for EFL Teachers were distributed among twenty three teachers which contained seven close ended questions and one open ended question. The first question was about the introduction of English from the beginning of primary level. Among the teachers, $73.91 \%$ strongly agreed, $26.08 \%$ teachers disagreed and $0 \%$ disagreed. Majority of the teachers agreed that English should get introduced from the time when learners start schooling. The second question was about the suitability of the EFL textbooks and materials according to the learners' needs. Among them $34.78 \%$ strongly agreed that the materials were suitable enough, $13.04 \%$ agreed but $52.17 \%$ disagreed. Therefore, the textbooks and study materials might get modified or changed according to the needs of $21^{\text {st }}$ century learners. The third question was about the necessity of motivation in teaching/learning process. Among the teachers, $78.26 \%$ strongly agreed while the rest agreed and none disagreed. The forth question asked was, "Do you think that a successful classroom depends on sound teacher-student relationship?" Among the participants, 69.56\% responded "Yes, I think so", while $30.43 \%$ answered "I think so with reservation", none denied. The fifth question was about the facilities provided for the EFL classrooms. Among the teachers $8.69 \%$ thought that the EFL classrooms were properly facilitated, $52.17 \%$ answered "I think so with reservation and $39.13 \%$ denied. Therefore, there remains a need for the proper facilities of EFL classrooms. The sixth question focused on the teaching strategies; whether the teaching strategies need to be updated or not. Among the participants 52.52\% strongly agreed, $39.13 \%$ agreed while $4.34 \%$ disagreed. The seventh question asked was, "Do you think that the assessment methods of the EFL learners are suitable enough?" Among them 13.04\% strongly agreed, 52.17\% agreed while $34.78 \%$ disagreed. The current assessment method depends a great deal on examination only, which can go through moderation. Several assessment methods can be implemented for effective evaluation.

The open-ended question was designed to get an idea about the EFL teachers' thoughts and expectations (See Appendix B). Many of the teachers suggested for EFL classes with fewer students, some asked for considering the global teaching and learning of EFL, while some suggested for in service training of the teachers. One colleague from King Khalid University 
suggested, "A team of teachers may document lesson plans, taking all the three stages (ie, presentation, practice and production) into consideration, in black and white for the use of teachers." Another colleague suggested, ".......... to introduce appropriate text books with required facilities in EFL classrooms." Colleague from Khamis International School suggested, “....not to memorize grammar rules only but to introduce more drills/exercises to reach the most effective way of teaching".

Table 8. EFL Teachers Responses of the questionnaire

\begin{tabular}{|c|c|c|c|}
\hline Questions & $\begin{array}{c}\text { Strongly Agree/Yes, I } \\
\text { think so(\%) }\end{array}$ & $\begin{array}{c}\text { Agree/I think so with } \\
\text { reservation (\%) }\end{array}$ & $\begin{array}{c}\text { Disagree/No } \\
(\%)\end{array}$ \\
\hline $\begin{array}{l}\text { 1. Should English be } \\
\text { introduced from the } \\
\text { beginning of primary } \\
\text { level }\end{array}$ & 73.91 & 26.08 & 0 \\
\hline $\begin{array}{l}\text { 2. Do the EFL } \\
\text { textbooks /materials } \\
\text { meet learners need }\end{array}$ & 34.78 & 13.04 & 52.17 \\
\hline $\begin{array}{l}\text { 3. Teaching/learning } \\
\text { process in KSA needs } \\
\text { further motivation }\end{array}$ & 78.26 & 21.73 & 0 \\
\hline $\begin{array}{l}\text { 4. Successful EFL } \\
\text { classroom depends on } \\
\text { sound teacher-student } \\
\text { relationship }\end{array}$ & 69.56 & 30.43 & 0 \\
\hline $\begin{array}{l}5 . \quad \text { Are } \\
\text { classrooms } \\
\text { facilitated }\end{array}$ & 8.69 & 52.17 & 39.13 \\
\hline $\begin{array}{lr}6 . \quad \text { Do } & \text { teaching } \\
\text { strategies } & \text { need } \\
\text { updating } & \\
\end{array}$ & 56.52 & 39.13 & 4.34 \\
\hline $\begin{array}{l}\text { 7. Are the assessment } \\
\text { methods suitable } \\
\text { enough }\end{array}$ & 13.04 & 52.17 & 34.78 \\
\hline
\end{tabular}




\section{Observation of the Researcher}

The researcher has been teaching in Saudi Arabia for more than eight years. She discusses with the students their problems and fears of learning English. She comes to know about their culture and above all about their likes and dislikes. Since she has been teaching blended courses for several years, it is easier for her to observe the performances of the students both face to face and online.

\subsection{Face to face classroom observation}

In the face to face classrooms, the learners lack vocabularies and therefore their pace of expression gets hindered. They do feel difficulties in constructing sentences and therefore become shy to speak. But if they get friendlier environment they tend to perform better. Random topics related to their day to day life motivate them to both speak and write. They do better in collaborative tasks.

\subsection{Online participation observation}

It was quite surprising for the researcher that the students who seem to be introvert in the face to face classroom, interacts better with the teacher online. Many of the students preferred online lectures rather than classroom lectures. One said, “............ feel teacher is teaching only me. I can ask anything to teacher without feeling shy...”. Many student feels that online classes are more informal rather than face to face class. Al-Shahrani and Al-Shehri(2012), argue for informal classroom environment and therefore suggested to introduce more informal and interactive medium like Facebook. The students were in liberty to contact the teacher using Facebook and Whatsapp. But, they were asked to contact using English only. It was wonderful to see that the learners were using Facebook and Whatsapp more to contact the teacher rather than Blackboard. They were writing more in these Social Medias rather than face to face classroom. The Faculty Innovation Centre of Cockrell School of Engineering in The University of Texas has been giving much importance on using Facebook in teaching. The learners of $21^{\text {st }}$ century cannot be ruled by rules and regulations but by love and friendship. In the recent years, the language teachers have deeply involved themselves to make language learning more effective, and motivating for the students (Vallance 1998; Donaldson \& Kotter1999; Yang 2001). The use of e-learning has brought a dynamic change in the language learning atmosphere (Young, 2003). The teachers may change their concepts of teaching if they themselves are enrolled as online students (Al-Mahmood \& McLoughlin, 2004). In fact, student -centered -learning approaches are proved to be more effective in higher education (Kember, 2009).

\section{Recommendations}

\subsection{Introducing English from the beginning of Primary Level}

Learning language is considered to be a natural instinct of a child. As learning any other language the children can learn L2 language if they are provided with enough exposure to it. (Jamali, 1991) suggests that in order to achieve greater success, the children need to be 
exposed to the L2 language, in the same way as they are exposed to the L1. Many researchers have conducted research on age effects of second language acquisition. Studies show that the young learners of L2 outperform older learners in various language skills like morph syntax (e.g. Birdsong \& Molis 2001, DeKeyser 2000, Johnson \& Newport 1989, Patkowski 1980), and pronunciation (e.g. Flege 1991, Flege \& MacKay 2004). Along with other subjects if the children learn English from the beginning of primary education, it will be easier for them to achieve accuracy in using this very language. But, teachers have to ensure that the learning environment is interesting and enjoyable. Interaction with teacher and classmates will lift the confidence level of the young learners and at the same time they will get the required exposure to English.

\subsection{Improving teaching/learning strategies in order to motivate the $21^{\text {st }}$ century learners}

$21^{\text {st }}$ century learners are surrounded by various sources to get attracted and stay busy. To develop the interest of our learners in learning English teachers need to motivate them first. A classroom environment which welcomes the learners to enjoy learning has to be created. Violand Sanchez(1998) in his research on brain, suggests for safe and supportive learning environment, free from threat or fear. The language teachers religiously need to think of innovative ideas to retain the interest of the learners. While planning and designing courses, selecting classroom activities teachers should consider the age, gender, culture and interest of the target learners.

Khan (2011) suggests:

Teaching is an art as well as a science. Without a proper development of teaching skills a teacher can't prove himself to be an effective instructor in his classes. He has to justify his position by showing different traits and skills while teaching the target learners. Apart from some well known qualities of a teacher in general such as qualification, training and experiences, a teacher is always expected to display some modest but significant behavior patterns and characteristics in his day to day interaction with the learners. If a teacher lacks the following characteristics he is supposed to attend teacher development programs in order to modify his teaching potential, attitude and readiness to deliver in the best possible manner. (P.70)

\subsection{Enrolling fewer numbers of students in FEL classes}

A crowded EFL classroom is de-motivating for both teacher and learner. A teacher can work very hard to improve and update his/her teaching strategies to meet the need of the students but all the efforts become in vain when the students are huddled in a classroom like cattle. Unfortunately, most of the EFL classes of Saudi Arabia are overcrowded. As a result, the teacher fails to give the required support to each individual. Simultaneously, learner loses the interest and keeps waiting for the bell to ring. Therefore the authorities and policy makers need to ensure that fewer numbers of students should enroll into EFL classes.

\subsection{Building sound student-teacher relationship}

A successful EFL classroom largely depends on sound student-teacher relationship. When a 
student feels comfortable in interacting with teacher, his/her confidence level develops and therefore feels free to discuss his/her problems instead of becoming shy or afraid. It is the teacher's prime responsibility to develop such relationship. Appreciation of smallest efforts made by the students can help the teacher to build strong bond.

\subsection{English alone should be the medium of instruction in an EFL class}

In an EFL classroom English should be the medium of instruction only. Relying on translation cannot bring successful outcome. If the learners fail to understand some specific word or expression, teachers can take the help of pictures, body languages etc. Teachers should not adopt a bilingual method. The tendency of both teachers and students towards using Arabic in language classroom minimizes the amount of English language exposure (Al-Abadan, 1993; Kannan, 2009). It takes 3/4 months to learn Arabic for the non-Arab workers who come to work in Saudi Arabia. Without taking any language course these workers learn Arabic within a short period of time and can communicate successfully. The reason is that, they get the maximum exposure to Arabic and they cannot switch for a second option. The Saudi EFL learners, unfortunately, get the least exposure to English. EFL classrooms are the only source which provides them with the exposure to English. There are other facilities like English news papers, TV programs, movies etc. But, the students hardly avail these opportunities. So, Arabic or controlled use of Arabic should be avoided in an EFL classroom.

\subsection{Selecting appropriate textbooks and teaching materials while designing curriculum}

Before selecting textbooks and designing curriculum, teachers, moderators, policy makers collaboratively need to determine the aims and objectives of any language program. According to the aims and objectives, the textbooks should be selected to meet the requirements of the target learners. Rahman (2013) in his study states:

The mushrooming growth of ELT around the world creates a condition to develop a large and varied number of textbooks and materials in the markets. As a result, many of the writers and publishers start writing and publishing ELT textbooks and materials for the commercial purpose with minimum level of linguistic features. Hence, these textbooks and materials fail to meet the learners' needs and baffled the syllabus designers and other administrative bodies to find out the best textbook from the market. Like many other countries, the syllabus designers and the higher authorities of various schools and universities of Saudi Arabia are also unable to choose an appropriate textbook for their students. Therefore, selection of appropriate ELT textbooks and materials is another point of concern. (P.115)

\subsection{Providing required facilities in EFL classrooms}

An EFL classroom requires extra facilities compared to a regular classroom. It needs to be facilitated with internet, multimedia, OHP projector, etc. There should be enough space in the classroom so that the teacher can make her students perform several activities needed for effective EFL teaching.

\subsection{Maximizing students exposure to English}




\section{Ml Macrothink}

The parents, the institutions and the government need to maximize the use of English in everyday life. The Saudi youth crave for technology. They become obsessed to get the latest mobile that comes to market, buy the latest laptop available. They like the youth of other countries stay busy with various social networking websites. Unfortunately, all these sources of entertainment are occupied by Arabic. Parents, institutions and government can take a step further and initiate replacing Arabic with English for the learners of $21^{\text {st }}$ century.

\subsection{Assessment method should focus on Evaluation instead of Examination}

Assessment method should be varied. In this research we have seen that students having obtained the maximum marks in English in school fail to express themselves correctly. Therefore, to evaluate the students properly, the assessment method should be modified.

Fareh's 2010 study finds the following:

A major factor that may account for the failure of the EFL programs is the official assessment policies adopted by ministries of education. General secondary exams, for example, have a fixed format or template on which students can be trained within a short period of time and pass the test easily without the need to study the required textbooks. Furthermore, the speaking and listening skills are not tested, and that may explain the poor quality of the students' oral and aural skills. (P. 3603)

\section{Conclusion}

The study made a humble effort to bring out the existing problems of EFL teaching in Saudi Arabia. In order to tackle the challenges English must be introduced from the beginning of primary level. To motivate the $21^{\text {st }}$ century learners, the teachers need to make the learning environment enjoyable by building sound teacher-student relationship and acquiring effective teaching strategies. While selecting text books and designing curriculums the moderators and policy makers need to focus on the aims of language programs and the interests of the learners. Less number of students should be enrolled in any EFL class. Assessment method should be diverse to bring out the best in the students. Finally, in an EFL classroom, English only should be the medium of instruction and interaction.

\section{References}

Al-Abdan, A. A. (1993). A study on using Arabic in teaching English in Saudi intermediate schools. King Saud University Magazine, 50(2), 396-426.

Al-Khasawneh, F. (2010). Writing for Academic Purposes: Problems Faced By Arab Postgraduate Students of the college of Business, UUM. ESP World, Issue 2(28), Volume 9 Available at: http://www.esp-world.info

Al-Mahmood, R., \& McLoughlin, C. (2004). Re-learning through e-learning: Changing conceptions of teaching through online experience. In R. Atkinson, C. McBeath, D. 


\section{Macrothink}

Jonas-Dwyer \& R. Phillips (eds), Beyond the comfort zone: Proceedings of the 21st ASCILITE Conference (pp. 37-47). Perth, 5-8 December. Retrieved January, 12, 2012 from: http:// www.ascilite.org.au/conferences/perth04/procs/al-mahmood.html

Al-Nasser, A. S. (2015). Problems of English Language Acquisition in Saudi Arabia: An Exploratory-cum-remedial Study. Theory and Practice in Language Studies, (5:8) Aug 2015, 1612-1619. Available at: http://0-gateway.proquest.com.fama.us.es/openurl?ctx_ver=Z39.88-2003\&xri:pqil:res_ver=0. 2\&res_id=xri:lion\&rft_id=xri:lion:rec:abell:R05249740

Al-Nofaie, H. (2010). The attitudes of teachers and students towards using Arabic in EFL classrooms in Saudi public schools - a case study. Novitas-royal (research on youth and language), 4(1), 64-95. Available at: http://www.novitasroyal.org/Vol_4_1/al-nofaie.pdf

Al shlowiy, A. (2014). Lifting Motivation Level of English Learners in Saudi Arabia. Arab World English Journal, 5(1), 129-136. Available at:

http://www.awej.org/index.php?option=com_content\&view=article\&id=429:ahmed-al-shlow iy\&catid $=46 \&$ Itemid $=152$

Al-Shammakhi, F., \& Al-Humaidi, S. (2015). Challenges Facing EFL Teachers in Mixed Ability Classes and Strategies Used to Overcome Them. World Journal of English Language Vol. 5, No. 3; 2015. https://doi.org/10.5430/wjel.v5n3p33

Al Shahrani, K., \& Al-Shehri, S. (2012). Conceptions and responses to e-learning: The case of EFL teachers and students in a Saudi Arabian university. Monash University Linguistics Papers, Vol 8 No 1 ISSN 1327-9130. (pp. 21-31) Available at: http://search.informit.com.au/documentSummary;dn=671764122005636;res=IELHSS

Ashraf, T. A. (2015). Blended Learning Communication Problems Confronting Saudi Learners of English. International Journal of English and Education, 4(3), 438-447.

Birdson D. \& M. Molis (2001). On the evidence for maturational constraints in second language acquisition. Journal of Memory and Language, 44, 235-249. https://doi.org/0.1006/jmla.2000.2750

Brown, H. (2007). Teaching by principles: An approach to language pedagogy. (3rd ed.). New York: Pearson Longman.

DeKeyser R. (2000). The robustness of critical period effects in second language acquisition. Studies in Second Language Acquisition, 22/4, 499-533. https://doi.org/10.13140/RG.2.1.3958.4486

Donaldson, R. P., \& M. Kotter, (1999). Language learning in cyberspace: Teleporting the classroom into the target culture. CALICO, 16(4), 531-543.

Ellis, R. (2008). The Study of Second Language Acquisition. Oxford: Oxford University Press. 


\section{Ml Macrothink}

Fareh, S. (2010). Challenges of Teaching English in the Arab World: Why Can't EFL Programs deliver as expected? Procedia Social \& Behavioral Sciences, 2, 3600-3604. https://doi.org/10.1016/j.sbspro.2010.03.559

Flege J. (1991). Age of learning affects the authenticity of voice onset time (VOT) in stop consonants $777 \mathrm{~h} 8 \mathrm{t} 8 \mathrm{~h} 8 \mathrm{j} 7$ produced in a second language. Journal of the Acoustical Society of America, 89, 395-411. Available at: http://www.ncbi.nlm.nih.gov/pubmed/2002177

Flege J. and I. MacKay (2004). Perceiving vowels in a second language. Studies in Second Language Acquisition, 26, 1-34.

Harmer, J. (2007). The practice of English language teaching. (4th ed.). Edinburgh: Pearson Education Limited.

Halliday, M., A. McIntosh and P. Strevens. (1972/1984) (8th impression) 'Learning Foreign Languages. In R. Nasr (ed.), Teaching and Learning English. Harlow: Longman.

Jamali, I. (1991). Language Exposure and Second Language Learning. The English Teacher, $X X$.

Jdetawy, L. (2011). Problems encountered by Arab EFL learners, LANGUAGE IN INDIA, 11(3). Retrieved June 10, 2011, from http://www.languageinindia.com/march2011/ arabicefllearnersfinal.pdf

Johnson, J. and E. Newport (1989). Critical period effects in second language learning: The influence of maturational state on the acquisition of English as a second language. Cognitive Psychology, 21, 60-99. https://doi.org/10.1016/0010-0285(89)90003-0

Kannan, R. (2009). Difficulties in learning English as a second language. ESP World, 5(26), Retrieved April 9, 2011, from http://www.esp-world.info/Articles_26/issue_26.htm

Khan, I. A. (2011). Challenges of Teaching/Learning English and Management. Global Journal of Human Social Science. , Vol. 11, Issue. 8, pp. 69-77. Available at: http://socialscienceresearch.org/index.php/GJHSS/article/view/220

Kember, D. (2009). Promoting student-centred forms of learning across an entire university. Higher Education, 58(1), 1-13.

Magno, et al. (2009). Assessing the level of English language exposure of Taiwanese college students in Taiwan and the Philippines. Asian EFL Journal. Retrieved September 13, 2010, from http://ssrn.com/abstract=1429345

Mukattash, L. (1983). "The problem of difficulty in foreign language learning", in: Dahiyat, E./Ibrahim, M. (eds.), Papers from the First Conference on the Problems of Teaching English Language and Literature at Arab Universities, Amman, University of Jordan.

Nation, P. (2003). The role of the first language in foreign language learning. Asian EFL Journal, 5(2). $\quad$ Retrieved $10 \quad$ September 2007, from: http://asian-efl-journal.com/1460/quarterly-journal/2003/06/the-role-of-the-first-language-inforeign-language-learning/ 


\section{Macrothink}

Patkowski M. (1980). The sensitive period for the acquisition of syntax in a second language. Language Learning, 30, 449-472. https://doi.org/10.1111/j.1467-1770.1980.tb00328.x

Rabab'ah, g. (2003). Communication problems facing Arab learners of English. Journal of Language and Learning. (pp. 180-197) Vol 3 No 1 ISSN 1740-4983. Retrieved April, 8, 2010 Retrieved from: http://www.eric.ed.gov/ERICWebPortal/recordDetail?accno=ED473079

Rahman, M. M. (2013). Teaching English in Saudi Arabia: Prospects and Challenges. Academic Research International. Vol.4 No.1. January 2013. Available at: http://www.savap.org.pk/journals/ARInt./Vol.4(1)/2013(4.1-13).pdf

Vallance, M. (1998). The design and use of an Internet resource for business English learners. ELT Journal, 52(1), 38-42.

Violand-Sanchez, E. (1998). The Triune Brain and Learning: Practical Insights for the Classroom. In J. Reid (Ed) Understanding learning styles in the second language classroom. 27-33.

Yang, S. C. (2001). Integrating computer-mediated tools into the language curriculum. Journal of Computer Assisted Learning, 17, 85-93.

Young, S. (2003). Integrating ICT into second language education in a vocational high school. Journal of Computer Assisted Learning, 19, 447-461.

\section{Appendix}

Appendix 1. Questionnaire for the EFL Students of KSA

Name of the Participant:

Date:

Dear Participant,

You are invited to participate in a research study titled "An Attempt to Boost EFL Teaching in Saudi Arabia". In order to design and develop EFL curriculum and to adopt effective teaching/learning strategies, it is important to collect and analyze the authentic data of students' attitudes, beliefs, expectations and performances. Therefore, you are requested to answer all the questions below carefully.

By completing and submitting this survey, you are indicating your consent to participate in the study. Your participation is appreciated.

\section{Tanzin Ara Ashraf}

Lecturer of English 


\section{Macrothink}

King Khalid University

\section{Saudi Arabia}

\section{Questionnaire for the EFL Students of KSA}

1. Do you agree that English is important for you to learn?
a. Strongly Agree
b. Agree
c. Disagree

2. Do you agree that English should be introduced from the beginning of Primary Level?
a. Strongly Agree
b. Agree
c. Disagree

3. Do you enjoy learning English?
a. Yes, I enjoy a lot
b. Yes
c. No

4. Do you agree that teaching/learning process in Saudi Arabia needs improvement?
a. Strongly Agree
b. Agree
c. Disagree

5. Do you think that the student-teacher relationship should be more informal?
a. Yes, I think so
b. I think so with reservation
c. No
6. Do you think that teacher should use Arabic in the classroom?
a. Yes, I think so
b. I think so with reservation
c. No

7. What were your average grade/score in English in school level? (Shade the box)

\begin{tabular}{|l|l|l|l|l|l|l|l|l|}
\hline A & B & C & D & E & F & G & H & Fail \\
\hline $95-100$ & $90-94$ & $85-89$ & $80-84$ & $75-79$ & $70-74$ & $65-69$ & $60-64$ & $<$ \\
\hline
\end{tabular}

Suggestions: (If you have any suggestion regarding EFL development, please feel free to share in the box below) 
Appendix 2. Questionnaire for the EFL Teachers of KSA

Name of the Participant:

Position:

Name of the Institution:

Date:

Dear Participant,

You are invited to participate in a research study titled "An Attempt to Boost EFL Teaching in Saudi Arabia". In order to design and develop EFL curriculum and to adopt effective teaching/learning strategies, it is important to collect and analyze the authentic data of teachers' observations, requirements, difficulties and experiences. Your valuable suggestions would assist us to tackle the challenges of EFL teaching and learning. Therefore, you are requested to answer all the questions below carefully.

By completing and submitting this survey, you are indicating your consent to participate in the study. Your participation is appreciated.

\section{Tanzin Ara Ashraf}

Lecturer of English

King Khalid University

Saudi Arabia

\section{Questionnaire for the EFL Teachers of KSA}

1. Do you agree that English should be introduced from the beginning of Primary Level?
a. Strongly Agree
b. Agree
c. Disagree

2. Do you agree that the EFL textbooks and teaching materials meet the learners' needs?
a. Strongly Agree
b. Agree
c. Disagree 


\section{Macrothink}

International Journal of English Language Education

ISSN 2325-0887

2018, Vol. 6, No. 1

3. Do you agree that teaching/learning process in Saudi Arabia needs further motivation?
a. Strongly Agree
b. Agree
c. Disagree

4. Do you think that a successful EFL classroom depends on sound teacher-student relationship?
a. Yes, I think so
b. I think so with reservation
c. No

5. Do you think that the EFL classrooms are properly facilitated?
a. Yes, I think so
b. I think so with reservation
c. No

6. Do you agree that teaching strategies need to be updated to meet the learners' needs?
a. Strongly Agree
b. Agree
c. Disagree

7. Do you agree that the assessment methods of the EFL learners are suitable enough?
a. Strongly Agree
b. Agree
c. Disagree

In order to tackle the challenges of EFL teaching and learning in Saudi Arabia we should--

\section{Suggestions:}

Appendix 3. Items for the Checklist for English Language Exposure

Instruction: Read each item and check how often is the situation applied to you. Shade the bubble corresponding to your answer 


\begin{tabular}{|c|c|c|c|c|c|}
\hline & Always & Often & Sometimes & Rarely & Never \\
\hline Home & $\mathrm{O}$ & $\mathrm{O}$ & $\mathrm{O}$ & $\mathrm{O}$ & $\mathrm{O}$ \\
\hline 1. My parents talk in English & $\mathrm{O}$ & $\mathrm{O}$ & $\mathrm{O}$ & $\mathrm{O}$ & $\mathrm{O}$ \\
\hline 2. My siblings talk in English & $\mathrm{O}$ & $\mathrm{O}$ & $\mathrm{O}$ & $\mathrm{O}$ & $\mathrm{O}$ \\
\hline 3. I converse in English with my cousins & $\mathrm{O}$ & $\mathrm{O}$ & $\mathrm{O}$ & $\mathrm{O}$ & $\mathrm{O}$ \\
\hline 4. My family encourages to speak in English & $\mathrm{O}$ & $\mathrm{O}$ & $\mathrm{O}$ & $\mathrm{O}$ & $\mathrm{O}$ \\
\hline \multicolumn{6}{|l|}{ Friends } \\
\hline 5. My friends speak English & $\mathrm{O}$ & $\mathrm{O}$ & $\mathrm{O}$ & $\mathrm{O}$ & $\mathrm{O}$ \\
\hline 6. I talk with my friends in English & $\mathrm{O}$ & $\mathrm{O}$ & $\mathrm{O}$ & $\mathrm{O}$ & $\mathrm{O}$ \\
\hline $\begin{array}{l}\text { 7. I write text messages to my friends in } \\
\text { English }\end{array}$ & $\mathrm{O}$ & $\mathrm{O}$ & $\mathrm{O}$ & $\mathrm{O}$ & $\mathrm{O}$ \\
\hline \multicolumn{6}{|l|}{ School/College/University } \\
\hline 8. My teacher speaks in English & $\mathrm{O}$ & $\mathrm{O}$ & $\mathrm{O}$ & $\mathrm{O}$ & $\mathrm{O}$ \\
\hline 9. My classmates speak in English & $\mathrm{O}$ & $\mathrm{O}$ & $\mathrm{O}$ & $\mathrm{O}$ & $\mathrm{O}$ \\
\hline 10. The medium of instruction is English & $\mathrm{O}$ & $\mathrm{O}$ & $\mathrm{O}$ & $\mathrm{O}$ & $\mathrm{O}$ \\
\hline 11. All the lectures are delivered in English & $\mathrm{O}$ & $\mathrm{O}$ & $\mathrm{O}$ & $\mathrm{O}$ & $\mathrm{O}$ \\
\hline 12. All the staff members understand English & $\mathrm{O}$ & $\mathrm{O}$ & $\mathrm{O}$ & $\mathrm{O}$ & $\mathrm{O}$ \\
\hline $\begin{array}{l}\text { 13. The medium of instruction in e-learning } \\
\text { is English }\end{array}$ & $\mathrm{O}$ & $\mathrm{O}$ & $\mathrm{O}$ & $\mathrm{O}$ & $\mathrm{O}$ \\
\hline \multicolumn{6}{|l|}{ Media } \\
\hline $\begin{array}{l}\text { 14. The medium of instruction in Facebook } \\
\text { is English }\end{array}$ & $\mathrm{O}$ & $\mathrm{O}$ & $\mathrm{O}$ & $\mathrm{O}$ & $\mathrm{O}$ \\
\hline 15. The medium of instruction in my & $\mathrm{O}$ & $\mathrm{O}$ & $\mathrm{O}$ & $\mathrm{O}$ & $\mathrm{O}$ \\
\hline
\end{tabular}




\begin{tabular}{|l|c|c|c|c|c|}
\hline computer is English & & & & \\
\hline $\begin{array}{l}\text { 16. The medium of instruction in my mobile } \\
\text { is English }\end{array}$ & $\mathrm{O}$ & $\mathrm{O}$ & $\mathrm{O}$ & $\mathrm{O}$ & $\mathrm{O}$ \\
\hline $\begin{array}{l}\text { 17. I browse web pages that are written in } \\
\text { English }\end{array}$ & $\mathrm{O}$ & $\mathrm{O}$ & $\mathrm{O}$ & $\mathrm{O}$ & $\mathrm{O}$ \\
\hline 18. I chat online in English & $\mathrm{O}$ & $\mathrm{O}$ & $\mathrm{O}$ & $\mathrm{O}$ & $\mathrm{O}$ \\
\hline 19. I listen to songs in English & $\mathrm{O}$ & $\mathrm{O}$ & $\mathrm{O}$ & $\mathrm{O}$ & $\mathrm{O}$ \\
\hline 20. I watch movies in English & $\mathrm{O}$ & $\mathrm{O}$ & $\mathrm{O}$ & $\mathrm{O}$ & $\mathrm{O}$ \\
\hline 21. I watch TV shows in English & $\mathrm{O}$ & $\mathrm{O}$ & $\mathrm{O}$ & $\mathrm{O}$ & $\mathrm{O}$ \\
\hline 22. I read magazines written in English & $\mathrm{O}$ & $\mathrm{O}$ & $\mathrm{O}$ & $\mathrm{O}$ & $\mathrm{O}$ \\
\hline 23. I read newspapers written in English & $\mathrm{O}$ & $\mathrm{O}$ & $\mathrm{O}$ & $\mathrm{O}$ & $\mathrm{O}$ \\
\hline 24. I read books written in English & $\mathrm{O}$ & $\mathrm{O}$ & $\mathrm{O}$ & $\mathrm{O}$ & $\mathrm{O}$ \\
\hline
\end{tabular}

Adopted from Mango et al 2009 and adapted by the researcher

\section{Copyright Disclaimer}

Copyright for this article is retained by the author(s), with first publication rights granted to the journal.

This is an open-access article distributed under the terms and conditions of the Creative Commons Attribution license (http://creativecommons.org/licenses/by/3.0/). 